\title{
Using PhETTM interactive simulation plate tectonics for initial teacher education
}

\author{
Bento Cavadas $^{1,2}$ and Sara Aboim ${ }^{3,4}$ \\ ${ }^{1}$ Department of Mathematics and Science, School of Education, Polytechnic Institute of Santarém, Santarém, Portugal \\ ${ }^{2} \mathrm{CeiED}$ - Interdisciplinary Research Centre for Education and Development, Lusófona University, Lisbon, Portugal \\ ${ }^{3}$ Department of Mathematics, Science and Technology, School of Education, Polytechnic Institute of Porto, Porto, Portugal \\ ${ }^{4}$ inED - Centre for Research and Innovation in Education, School of Education, Polytechnic Institute of Porto, Porto, Portugal \\ Correspondence: Bento Cavadas (bento.cavadas@ese.ipsantarem.pt)
}

Received: 19 July 2020 - Discussion started: 9 September 2020

Revised: 12 December 2020 - Accepted: 22 December 2020 - Published: 10 February 2021

\begin{abstract}
Using digital educational resources (DERs) in science education is an effective way of promoting students' content knowledge of complex natural processes. This work presents the usage of the digital educational resource CreativeLab_Sci\&Math | Plate Tectonics, designed for exploring the PhET ${ }^{\mathrm{TM}}$ Plate Tectonics simulator, in the context of the education of pre-service teachers (PSTs) in Portugal. The performance of the PSTs was analysed based on the five tasks into which the DER was organized. Results show that the DER contributed to the successful achievement of the following learning outcomes for PSTs: describing the differences between the oceanic crust and continental crust regarding temperature, density, composition and thickness, associating the plate tectonic movements with their geological consequences, and identifying the plate tectonic movements that cause the formation of some geological structures. Results also show that PSTs considered the PhET ${ }^{\mathrm{TM}}$ Plate Tectonics simulator a contributor to their learning about plate tectonics.
\end{abstract}

\section{Introduction}

This work presents the implementation of the digital educational resource (DER) of CreativeLab_Sci\&Math | Plate Tectonics, designed under the CreativeLab_Sci\&Math project (Cavadas et al., 2019). This resource is a structure guide with several tasks that explore the PhET ${ }^{\mathrm{TM}}$ Plate Tectonics simulator from the PhET Interactive Simulations ${ }^{\mathrm{TM}}$ of the University of Colorado Boulder. This simulator aims to allow users to explore the plate tectonic dynamics on the Earth's surface through the manipulation of different variables, such as temperature and density and crust types (oceanic crust and continental crust). The tasks available to users within the educational resource were organized according to the following learning outcomes (LOs):

1. LO 1: Describe the differences between the oceanic crust and the continental crust regarding temperature, density, composition and thickness.

2. LO 2: Associate the tectonic plate movements with their geological consequences.

3. LO 3: Identify the tectonic plate movements that cause the formation of certain geological structures.

This educational resource was applied to the Initial Teacher Education (ITE) programme in two Portuguese teacher training institutions (TTIs). The results of its implementation in the academic year of 2019-2020 are presented in this work. The main question that guided the work was: "What was the contribution of the educational resource of CreativeLab_Sci\&Math | Plate Tectonics to the pre-service teachers' learning about plate tectonics?"

\section{Learning and teaching about plate tectonics}

In the history of science, explanations for the origins of the Earth's surface evolved from the contracting Earth hypothesis to the continental drift theory (Wegener, 1922) and, later, to the more unified and integrative theory of plate tectonics (Frankel 2012a, b, c). The theory of plate tectonics is 
supported by evidence associated with seafloor spreading, seafloor sediments, magnetic anomalies and the geological meaning of mid-ocean ridges, rifts, oceanic trenches and transform faults. Studies about convection, the formation of mountain ranges, the Benioff zone, the subduction process, the tectonic plate boundaries and their characteristics also contributed to the development of the plate tectonics theory (Wilson, 1976; Frankel, 2012c).

The new knowledge about Earth dynamics suffered didactic transposition into science textbooks (Cavadas, 2019) and promoted reflections about plate tectonics teaching. In fact, a few years after the enunciation of plate tectonics theory by Morgan, in 1967 (Frankel, 2012c), its didactic transposition to educational contexts was contemplated in studies, such as in the work of Glenn (1977). This researcher presents suggestions for teaching elementary school students about continental drift and plate tectonics. Other works were published in the following decades in Portugal about the didactic transposition of continental drift and plate tectonics into textbooks (Cavadas, 2019; Cavadas and Franco, 2009; Faustino et al., 2017; Santos et al., 2010), the teaching of those subjects as the history of science using epistemological perspectives (Almeida, 2000; Praia, 1995; Vasconcelos et al., 2013), and specific topics related to plate tectonics, such as palaeomagnetism (Correia, 2013).

Students' misconceptions about plate tectonics were also comprehensively studied (Borges, 2002; Dolphin and Benoit, 2016; Francek, 2013; Mills et al., 2017). In a global study about 500 misconceptions on geosciences, Francek (2013) concluded that about $19 \%$ of the misconceptions were related to plate tectonics. Regarding this matter, in a sample of 16-17-year-old Portuguese students, Marques and Thompson (1997) identified misconceptions about plates and their motions, such as the idea that plates are arranged like a stack of layers $(64 \%)$, the same tectonic plate mechanism causes continental and oceanic mountain ranges $(40 \%)$ or that magnetic polar wandering causes the motion of plates (34\%). In a more recent study, Mills et al. (2017) concluded that many 14-year-old students $(n=95)$ also had misconceptions about the nature, movement and boundaries of tectonic plates and the occurrence of geological events at tectonic plate boundaries. Many students thought, for example, that tectonic plates were located underground, and that they were not exposed on the Earth's surface, that the Earth's spinning axis causes the tectonic plates to move, that tectonic plate boundaries are located at the edges of continents or countries, and that earthquakes are caused when two tectonic plates suddenly crash together (Mills et al., 2017). The identification of these misconceptions about plate tectonics in different studies is clear evidence of the persistency of those misconceptions among students.

According to Marques and Thompson (1997), traditional Earth science teaching methodologies in Portuguese schools do not contribute to the eradication of students' misconceptions about plate tectonics. Exploiting the potential of digital resources for teaching plate tectonics is an alternative approach. Some studies found that learning about some contents of plate tectonics using digital resources, such as Google Earth ${ }^{\circledR}$ (Bitting et al., 2019; Ferreira, 2016), is beneficial for students, for example, in the learning of mountain range and volcano formation and the distribution of earthquakes (Bitting et al., 2019). Mills et al. (2019) showed that the use of a student-constructed animation by 11-14-yearold students for explaining the processes that occur in tectonic plate boundaries contributed to their better performance in a geological quiz, i.e. GeoQuiz, about those processes. Therefore, Mills et al. (2019) concluded that the work proposals based on representations of plate tectonic processes contribute to students' learning about those processes.

\section{Interactive simulations and science learning}

Computer simulations have evolved considerably from the first simple models, in which interactivity was possible with only one or two defined parameters, to current simulations that are more complex and with more realistic visual representations which allow the user to make changes and observe their effects in real time. In addition, the simulations have unique characteristics which are not present in many other learning tools, such as interactivity, animation, dynamic feedback, exploration and discovery (Podolefsky et al., 2010).

One of the most effective ways of solving a problem is by simulating reality and replicating one specific situation for better analysis and study (Tan, 2007). The use of digital simulations is very important in Earth sciences since it allows the study of certain processes that cannot be reproduced in the laboratory and, therefore, the exploration of the relations between the theoretical framework and the simulations of the observed geological processes. Simultaneously, it improves the motivation and interest of students in classes (Nafidi et al., 2018; Quintana et al., 2004; Pinto et al., 2014). Digital simulations can be used as educational resources to promote observation, communication, analysis, hypothesis formulation and the critical thinking skills of students (Nafidi et al., 2018). Problem-solving and scientific discovery learning in digital simulations allow students to build new and meaningful knowledge about what they are learning (de Jong and Joolingen, 1998) and reflect about their learning in a metacognition process (Droui, 2014; Nafidi et al., 2018).

In the context of teacher education, other studies revealed the benefits of the use of simulations (Trundle and Bell, 2010) and multimodal digital animations, known as Slowmation, for science learning (Hoban et al., 2011; Paige et al., 2016), validating the use of digital education resources in teacher science education. However, additional research to assess the impact of specific simulators on content knowledge is needed (Phuong et al., 2013). 
Regarding $\mathrm{PhET}^{\mathrm{TM}}$ simulations that were used in the present study, some works showed that they are very useful for engaging students and improving their interest and knowledge in many scientific fields (Hensberry et al., 2013; Lancaster et al., 2013; McKagan et al., 2008; Perkins et al., 2012; Wieman et al., 2010). PhET ${ }^{\mathrm{TM}}$ simulations are created to promote science education, are freely available on the $\mathrm{PhET}^{\mathrm{TM}}$ website and are more effective for conceptual understanding (Podolefsky et al., 2010; Perkins et al., 2012). The simulations are designed with little information in the form of text, so that students can easily use it in the classroom, in a laboratory or as homework (Podolefsky et al., 2010). Since $\mathrm{PhET}^{\mathrm{TM}}$ simulations are digital resources available online, they can be used and explored in the distance and online learning modality, as recommended by Commonwealth of Learning in their statement regarding "Keeping the doors of learning open" during Covid-19 (COL, 2020).

The current work is innovative because it is focused on the use of a simulator, PhET ${ }^{\mathrm{TM}}$ Plate Tectonics, in the context of teacher training about plate tectonics. There is also the novelty of the creation and the implementation of the DER resource CreativeLab_Sci\&Math Plate Tectonics because it resulted from the collaboration between teachers of two different schools of education, enabling the exchange of experiences and practices between institutions that are involved in teacher education, including online learning experiences.

\section{Methods}

We used an exploratory case study research design (Swain, 2017) because our intent was to obtain first insights about the contribution of the educational resource CreativeLab_Sci\&Math | Plate Tectonics to the learning of preservice teachers (PSTs) about plate tectonics.

\subsection{Participants}

The participants in this study are 68 PSTs from two Portuguese TTIs, ranging in age from 19 to 38 years old. Upon graduation, these PSTs can teach children from kindergarten to elementary school. In the Portuguese school system, elementary schools are frequented by 11-12-year-old students. The high school background of the majority of PSTs is linguistics. Only a few of them attended science courses in high school before starting their higher education studies.

The study followed the guidelines and recommendations of the authors' research centre ethical committees. All participants authorized the use of their data and written productions for science education research purpose through informed voluntary consent. Participants were clearly informed that they could withdraw from the investigation at any time, and that their data would be anonymized during the data analysis.

\subsection{Design and implementation of the educational resource}

The educational resource CreativeLab_Sci\&Math | Plate Tectonics was implemented during the 2 preceding academic years before the current implementation, in the context of the ITE of one Portuguese TTI. The educational resource was constantly improved, concerning its scientific content, didactic sequence, task approach and the use of the simulator's capabilities during that implementation, following feedback from the PSTs and teachers' reflections. It was also peer reviewed by another TTI science education teacher. The internal validity (Cohen et al., 2007; Swain, 2007) of the resource was reinforced by its submission to an open scientific educational resources repository. During the peer review, the resource was carefully evaluated by geology and other science education teachers from universities. This process improved the content validity (Cohen et al., 2007; Fraenkel et al., 2012) of the educational resource, refining its format and the accuracy of the scientific content and questions so that they are clearly understood by the participants, as suggested by Swain (2017), which allowed explanations that better fit the data (Cohen et al., 2007).

The final version of the resource was organized in tasks in a Google Forms ${ }^{\circledR}$. The Google Forms ${ }^{\circledR}$ has the advantage of allowing the inclusion of different types of questions (multiple choice, checkboxes, etc.) and resources (text, images, videos and links) and the benefit of giving immediate feedback to the students about their performance in each task and globally. The educational approach used was guided enquiry because it is the didactic approach recommended for the use of PhET ${ }^{\mathrm{TM}}$ simulations (PhET, 2014). Accordingly, in the design and implementation of the educational resource, the following instructional recommendations for $\mathrm{PhET}^{\mathrm{TM}}$ simulations were considered:

1. Specific learning outcomes were defined (e.g. LO 1, LO 2 and LO 3).

2. Minimal instructions for the use of the simulator were delivered, as it was developed with the aim of allowing free exploration by PSTs, whose role is to construct a useful meaning from those explorations.

3. PSTs were prompted to mobilize their previous knowledge about plate tectonics in the tasks.

4. PSTs were encouraged to use their problem-solving skills to give correct answers to the problems posed in the tasks.

5. Tasks were structured to be performed in pairs of PSTs, encouraging cooperation and discussion of ideas.

6. PSTs were asked to reflect on the contribution of the educational resource to their learning. They were also asked if there were any suggestions with respect to addressing the improvement of the educational resource. 
Table 1 shows the relationship between the tasks and the learning outcomes.

The resource was implemented in classes of two different Portuguese TTIs. The educational resource was implemented in an Earth and life sciences curricular unit in one of the TTIs and in a geosciences curricular unit in the other TTI. The tasks were performed in pairs of PSTs. This had the advantage of promoting discussion between them. The time frame PSTs had to accomplish the tasks was $2 \mathrm{~h}$.

\subsection{Methods of data collection}

Multiple sources of evidence were used for answering the research question, which is a defining feature of case studies (Swain, 2017). The production of the PSTs about the educational resource collected through a Google Forms ${ }^{\circledR}$ questionnaire, mainly with multiple choice questions, was one of those sources. The questionnaire was made available to PSTs of two Portuguese TTIs in science curricular units in an online teaching context. This digital questionnaire has the advantage of producing an output with the global data of all the students' answers. This output was the main instrument of quantitative data collection used.

Another method of data collection used was a short survey of reflections by PSTs on the contribution of the educational resource to their learning, which included their suggestions for its improvement. These reflections were used to collect more qualitative data about the learning of the PSTs using the educational resource CreativeLab_Sci\&Math | Plate Tectonics. Furthermore, the reflections of the PSTs were also used to enhance the resource.

Research teachers' course materials were also collected. These materials were used for describing the design and the implementation of the educational resource. Observation of the work of the PSTs was also considered, but that method of data collection could not be implemented due to the Covid19 pandemic and the transition to online teaching.

\subsection{Data analysis}

A detailed description of each task is presented in the results and discussion section. The performance of the PSTs was analysed for each question of tasks A, B and C. The correct answers for each question were quantified, the relative frequency was calculated and possible justifications for students' achievements were presented.

A sample of students (19 pairs) was asked to give feedback about the contribution of the educational resource to their learning of plate tectonics and if they had any suggestions for the improvement of the resource at the end of the tasks. Through a post-categorization of the answers of the PSTs, a qualitative analysis of these data was done using coding categories. The researchers followed the instructions of Fraenkel et al. (2012) in the coding process. The sentences written by the PSTs were the unit of analysis (Fraenkel et al., 2012). From the coding process, two main categories of analysis emerged, namely contributions to learning and improvement suggestions, and there were three subcategories for each main category. A first analysis, done by one of the researchers, was followed by a second analysis, by the other researcher, to ensure internal validity. When divergences in the categorization process occurred, a discussion was held until a consensus was reached. Extracts from the answers of the PSTs were used to better support the analysis.

\section{Results and discussion}

The results of the simulations application for each task and a discussion of PST performance are presented in this section. Figures 1 to 8 , shown in this section, are screenshots from the PhET ${ }^{\mathrm{TM}}$ Interactive Simulations of the University of Colorado Boulder.

\subsection{Task $A$ - characteristics of crust}

In task A1, PSTs had to explore different crust conditions, such as density, temperature and thickness, and classify three statements (A1.1., A1.2. and A1.3.) as true or false for the study of crust characteristics. Another purpose of the A1 tasks was to provide PSTs with a first approach to the simulator sections and toolbox and engage them in the following tasks.

Regarding statement A1.1., i.e. "Oceanic crust is denser than continental crust", PSTs could use the density meter in the toolbox to compare the density of both crusts, as shown in Fig. 1. That exercise could allow them to perceive that the oceanic crust density is higher than the continental crust.

Concerning statement A1.2., i.e. "The temperature of oceanic crust is higher than continental crust at $5 \mathrm{~km}$ depth", PSTs were expected to use the thermometer and the ruler in the toolbox. PSTs would then observe that the temperature of oceanic crust is slightly higher than continental crust by positioning the thermometer at the depth of $5 \mathrm{~km}$ in oceanic and continental crust, as shown in Fig. 2.

The statement A1.3. was related to crust thickness, i.e. "Oceanic crust is thicker than continental crust." PSTs would perceive, by using the ruler in the toolbox, that this statement is false because continental crust is thicker than oceanic crust.

In task A2, PSTs had to analyse the vertical movements of the crust by changing some variables. In task A2.1., they were expected to analyse what happens to the crust when its temperature increases by maintaining the same density and thickness in the panel labelled "My crust". By doing so, they could verify that the crust moves slightly upward. They would observe the opposite phenomenon when decreasing the temperature. After that, they could select one of two possible answers. The following answer is correct one: "As the temperature of crust increases, the density of the materials 
Table 1. Relationship between the educational resource CreativeLab_Sci\&Math | Plate Tectonics tasks and the learning outcomes.

\begin{tabular}{ll}
\hline Tasks & Learning outcome \\
\hline Task A1 and A2 - characteristics of crust & $\begin{array}{l}\text { LO 1: Describe the differences between the oceanic crust and the continental crust } \\
\text { regarding temperature, density, composition and thickness. }\end{array}$ \\
\hline Tasks B1 and B2 - plate movements & LO 2: Associate the tectonic plate movements with the geological consequences. \\
\hline Task C - enquiry about plate tectonics & $\begin{array}{l}\text { LO 3: Identify the tectonic plate movements that cause the formation of some } \\
\text { geological structures. }\end{array}$ \\
\hline
\end{tabular}
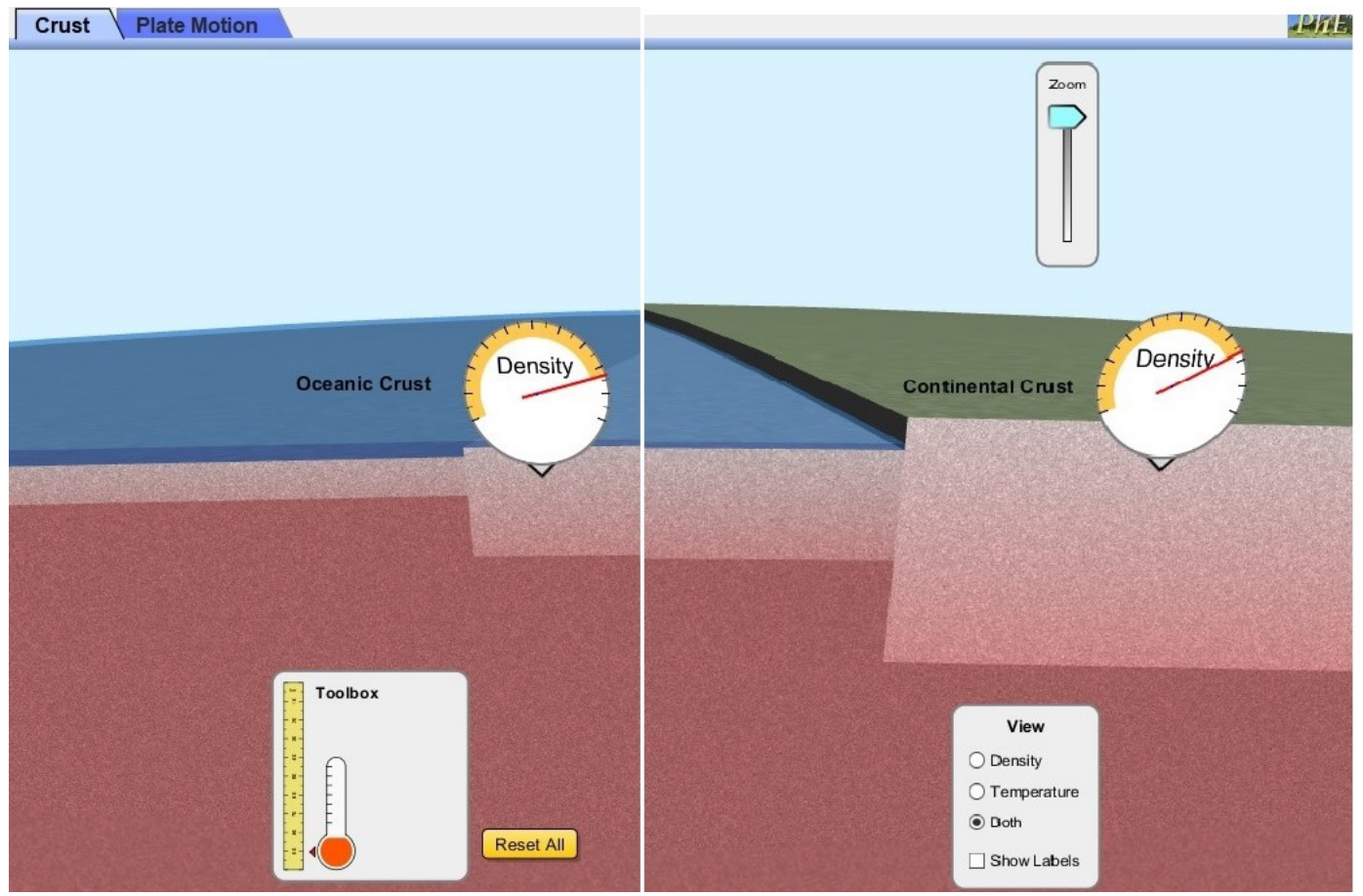

Figure 1. Density values of oceanic and continental crust. Caption from PhET ${ }^{\mathrm{TM}}$ Plate Tectonics.

that compose it decreases. The crust which is less dense rises upward as a result of the denser composition of the mantle."

Task A2.2. is related to the density of the crust. PSTs could conclude that the following answer is the correct one through changing the crust's silica and iron composition in "My crust" and maintaining the same temperature and thickness (Fig. 3): "There is a direct relationship between the percentage of iron in the composition of the crust and its density. The denser crust descends as opposed to the less dense composition of the mantle."

Table 2 shows the results for PST tasks A1.1. to A2.2.

The results show that, using the simulator, PSTs performed very well on the A1 tasks. The performance results on task A1.2 were relatively lower in comparison with the other A1 tasks. This could be due to the smaller differences in the temperature of both crusts that are difficult to observe on the simulator thermometer's scale at $5 \mathrm{~km}$ depth. On the other hand, a small mistake in the positioning of the thermometer at $5 \mathrm{~km}$ depth could also cause an incorrect reading of the temperature.

As in task A1, PST scores in task A2 were also very high. The observation of the crust movements in the simulator was very helpful for identifying the influence of the crust's temperature and composition on its movements in relation to the Earth's mantle. Some incorrect answers in A2.1. may have resulted from the fact that the crust movement, due to temperature variation, is relatively small and sometimes difficult to observe in the simulator. In A2.2., some incorrect answers may have resulted from a poor conceptual knowledge of the meaning of density, since many PSTs had a poor background in geosciences. However, the good results on tasks A2.1. and A2.2. could contribute to avoiding the common misconception that "Vertical forces push up the bottom of the oceans and originate the continents" (Marques and Thompson, 2006, p. 207). 


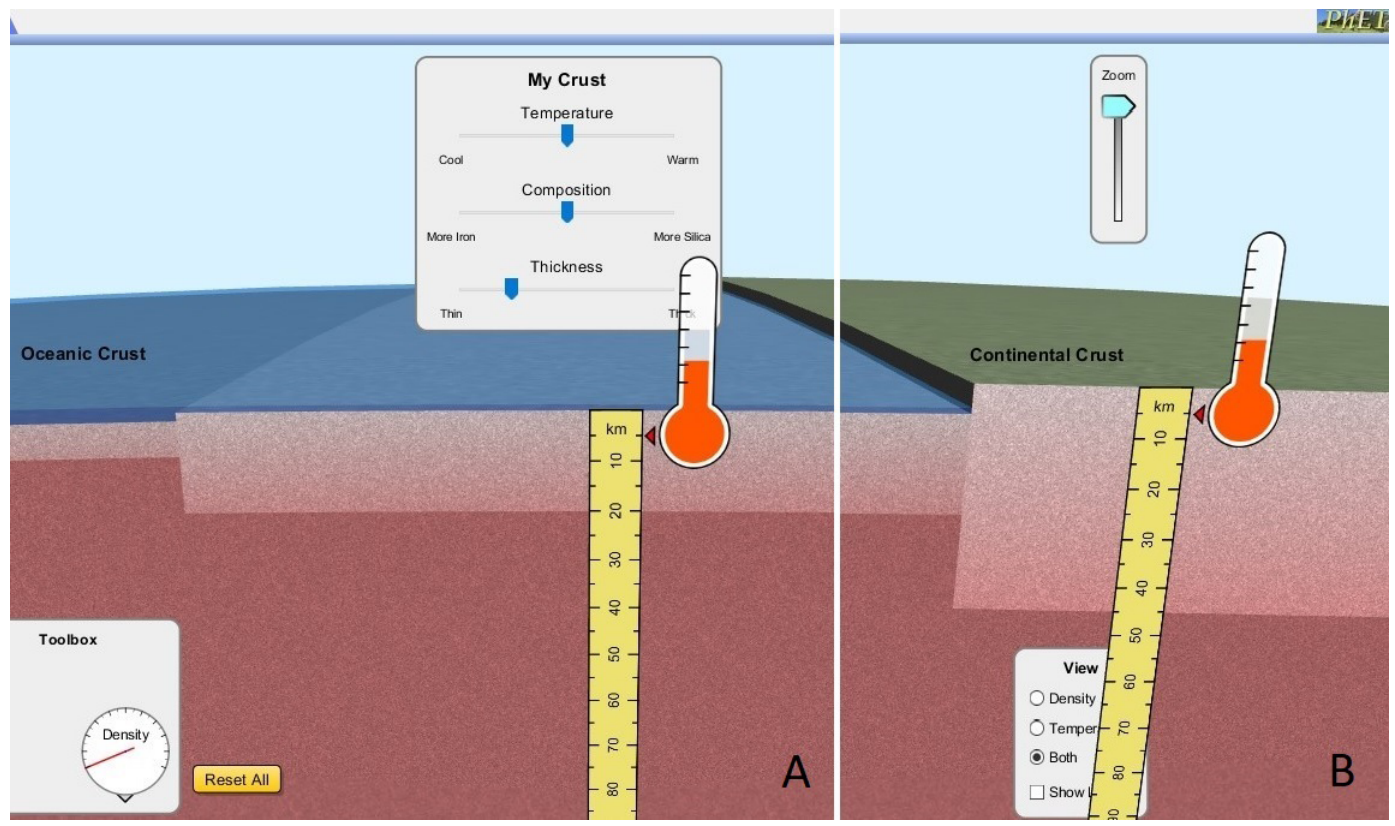

Figure 2. Oceanic (a) and continental crust (b) temperature at $5 \mathrm{~km}$ depth. Caption from PhET TM Plate Tectonics.

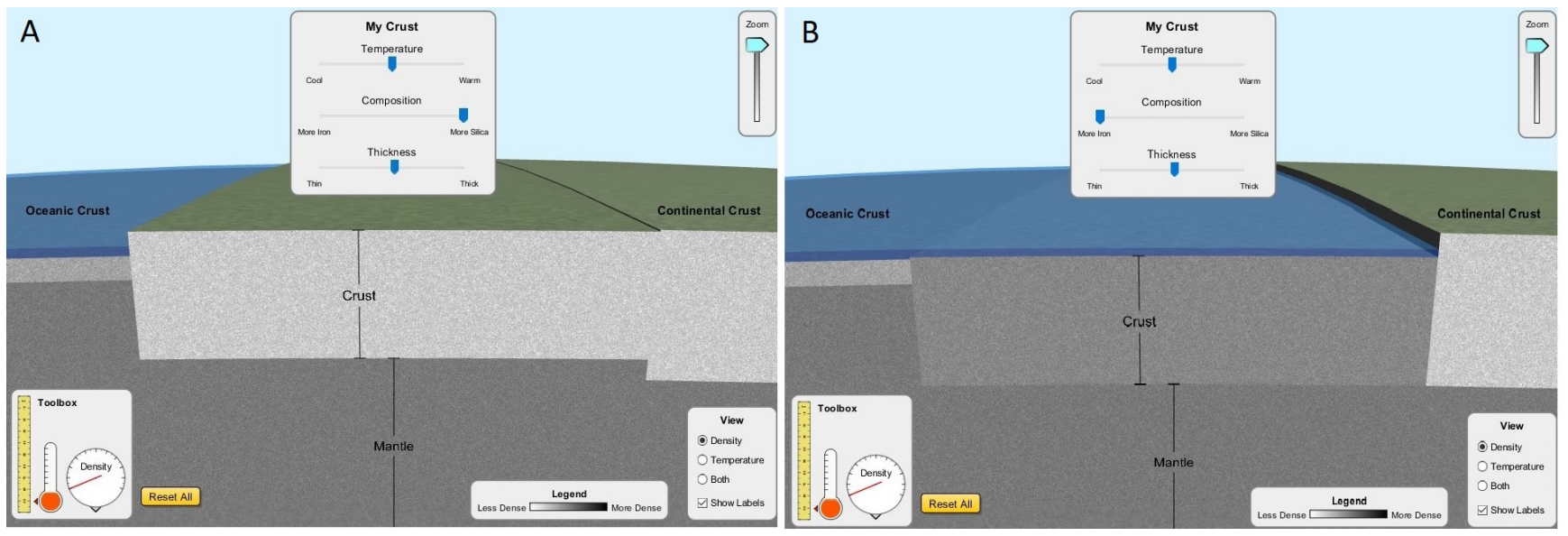

Figure 3. Comparison between the movements of a crust that is richer in silica (a) and a crust that is richer in iron (b). Caption from PhET ${ }^{\mathrm{TM}}$ Plate Tectonics.

\subsection{Task B - plate movements}

Task B was designed with the purpose of studying the tectonic plate movements (Fig. 4). Initially, PSTs selected the section "Plate movements" and reproduced the tectonic situations presented trough captions of PhET ${ }^{\mathrm{TM}}$ Plate Tectonics in each task.

The initial tasks (B1) were designed for the analysis of processes that occur on convergent plate boundaries. In task B1.1., PSTs could examine the collision between a plate with continental crust and a plate with old oceanic crust (old oceanic plate). They were given four options for the answer. PSTs could notice through playing the simulation that the correct one was the answer stating that the oceanic crust suffers subduction under the continental crust.

Task B1.2. is similar to B1.1., with the difference being that the collision is between a plate with continental crust and a plate with recent oceanic crust (new oceanic plate). In the same way, the recent oceanic crust suffers subduction under continental crust.

In task B1.3, PSTs could simulate a collision between a plate with continental crust and new or old oceanic plates and compare the subduction angle of the last ones. Using the simulator, they could notice that the angle of subduction on an old oceanic crust is greater than the angle of subduction on a recent oceanic crust (Fig. 5) 
Table 2. Results of pre-service teachers' tasks A1.1. to A2.2.

\begin{tabular}{lr}
\hline Task & $\begin{array}{r}\text { Relative frequency of } \\
\text { correct answers }(n=68)\end{array}$ \\
\hline A1.1. Comparison of oceanic and continental crust density. & $80.9 \%$ \\
Correct answer - "Oceanic crust is denser than continental crust." & $76.5 \%$ \\
\hline A1.2. Comparison of oceanic and continental crust temperature. & $100 \%$ \\
Correct answer - "The temperature of oceanic crust is higher than continental crust at $5 \mathrm{~km}$ depth." & $83.8 \%$ \\
\hline A1.3. Comparison of oceanic and continental crust thickness. & \\
Correct answer - "Oceanic crust is thicker than continental crust" & $88.2 \%$ \\
\hline A2.1. Select the process that occurs when crust's temperature increases. \\
Correct answer - "As the temperature of the crust increases, the density of the materials that \\
compose it decreases. The crust which is less dense rises upwards as a result of the denser \\
composition of the mantle." \\
\hline A2.2. Select the process that occurs when crust's density increases. \\
Correct answer - "There is a direct relationship between the percentage of iron in the composition \\
of the crust and its density. The denser crust descends as opposed to the less dense composition \\
of the mantle"
\end{tabular}
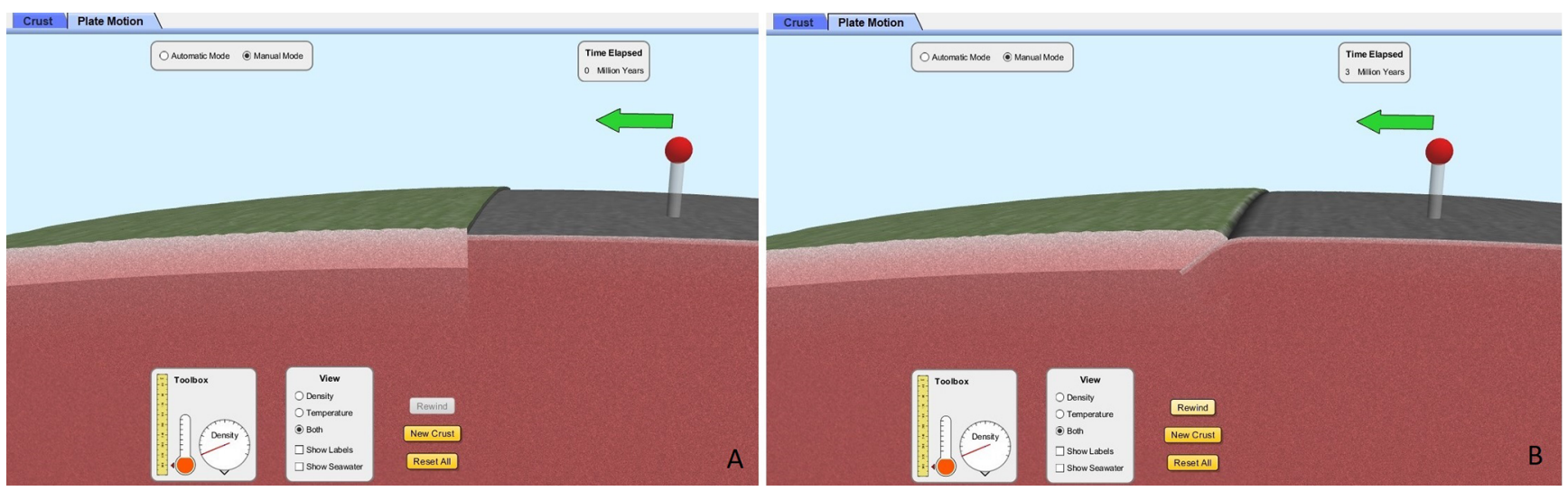

Figure 4. First image provided to PSTs that represents a convergent movement with continental and oceanic crust (a). The simulation shows that oceanic crust suffers subduction under the continental crust (b). Caption from PhETTM Plate Tectonics.

The last task concerning convergent plate boundaries (task B1.4.) explores the location of volcanoes that are formed due to the collision between a plate with continental crust and an old or new oceanic plate. Using the simulator, PSTs could notice that the collision between a plate with continental crust and an old oceanic plate causes volcanoes closer to the continental margins than the volcanoes resulting from the collision with a new oceanic plate (Fig. 6).

The processes that occur in divergent plate boundaries are analysed in the following tasks. In task B2.1., PSTs must classify the following statement as being true or false: "A rift is only formed due to the divergence of continental crust." To explore this situation, PSTs could simulate the divergent movements of continental crust, continental crust and old oceanic crust, continental crust and new oceanic crust, old oceanic crust and new oceanic crust. They could notice that the statement is false after those simulations because the simulator shows that a rift could also be formed due to the divergence of old oceanic crust (Fig. 7).

In task B2.2., Fig. 8a was provided to PSTs. After observing the tectonic situation represented, PSTs could select the correct option to complete this statement: "The type of plate movement that causes the formation of oceanic crust is...". They could conclude, through the manipulation of the different arrows, that the correct option is ".. divergent movements (red arrows)", as shown in Fig. 8b.

Table 3 shows the results of the PST tasks for B1.1. to B2.2.

The results show that PSTs performed very well on all B1 tasks. For B1.1., B1.2. and B1.3., using the simulation, they verified that an old or new oceanic plate always suffers subduction in a convergent movement with a continental 

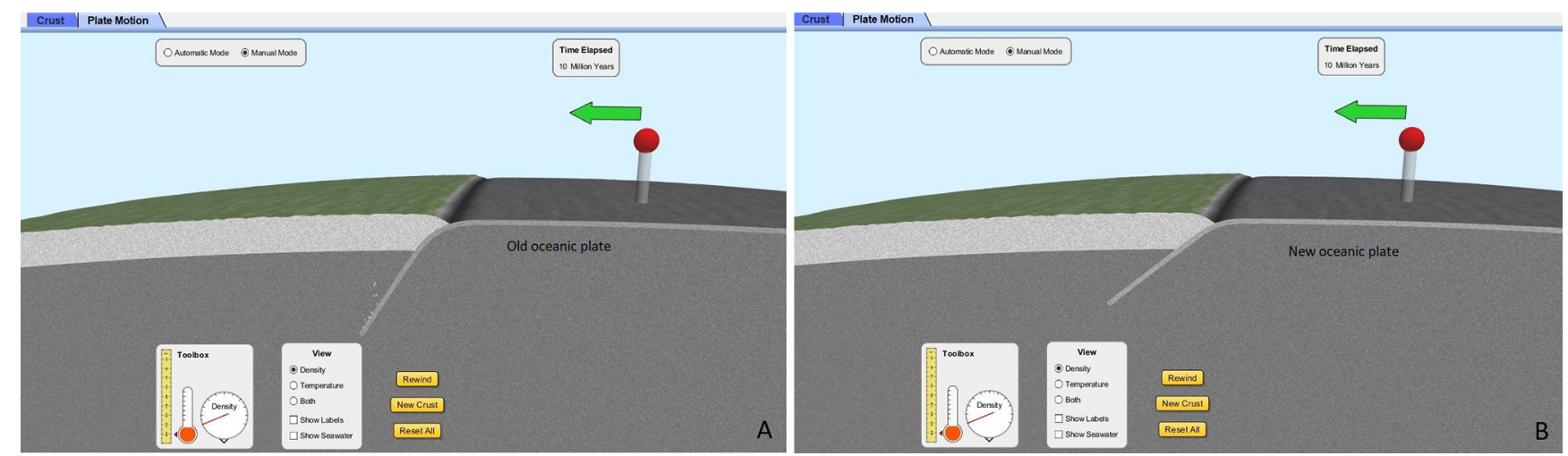

Figure 5. Subduction angles resulting from the collision between a plate with continental crust and an old oceanic plate (a) and a new oceanic plate (b). Caption from PhET TM Plate Tectonics.
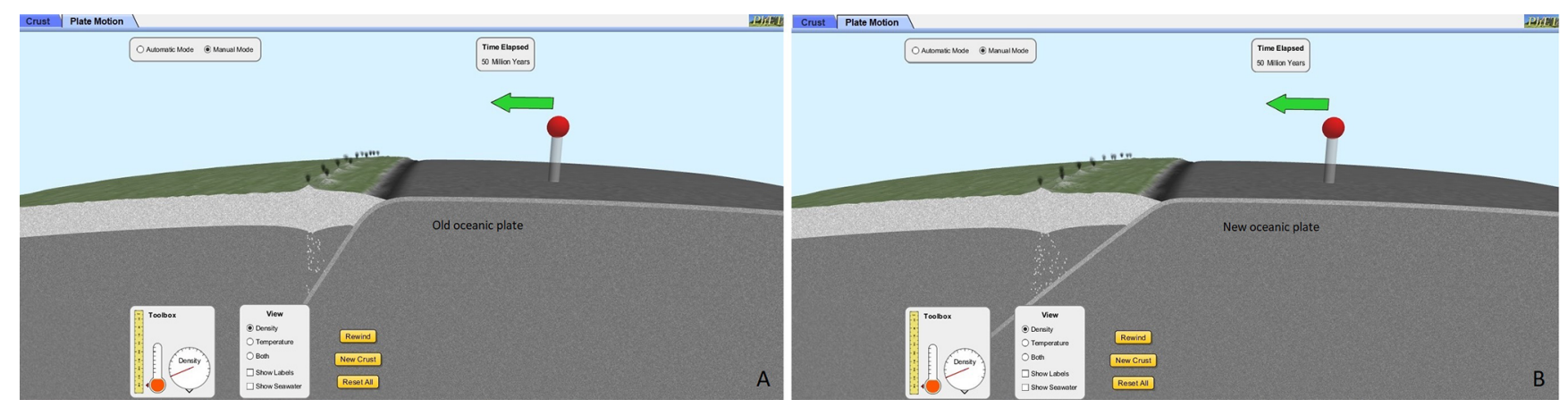

Figure 6. Location of volcanoes relative to the continental margin resulting from the collision between a plate with continental crust and an old oceanic plate (a) and a new oceanic plate (b). Caption from PhETTM Plate Tectonics.

crust. They could also determine that this phenomenon occurs due to different crust densities. By using the simulator, PSTs noticed that old or new oceanic plates suffer subduction under continental crust because of their higher density. In addition, PSTs also observed that the subduction angle is different on both convergent plate boundaries (B1.3.) and, consequently, so is the location of volcanoes on continental margins (B1.4.). B1 tasks have the advantage of moving PSTs away from common misconceptions about what happens when two tectonic plates push together, e.g. that “ $\ldots$ the size, speed, and/or relative position of the plates determines how they interact", "... both plates are pushed upward to form volcanoes" or "... for millions of years the larger tectonic plate is pushed upward" (Mills et al., 2017, pp. 303304).

The performance of PSTs in task B2.1. was poorer due to the lack of exploration of all the plate movements combinations that could cause a rift formation. Many PST groups just simulated the divergence of continental crust, as shown in Fig. 8a, erroneously concluding it was the only possibility for rift formation. However, this task also had the advantage of moving PSTs away from common misconceptions about the processes that happen when two tectonic plates separate, e.g. "... an empty gap forms" or "... loose rock fills the gap that forms between them" (Mills et al., 2017, p. 303), since they could observe that, when two tectonic plates separate, a rift is formed. Concerning B2.2., PST performance was better because they simulated what happened with all movements, i.e. divergent movements (red arrows), convergent movements (green arrows) and transform movements (blues arrows). The simulator shows that divergent movements (red arrows) are the only ones that can cause the formation of oceanic crust. The performance of PSTs that was achieved through replicating plate movements is an example of Tan's (2007) idea that simulating reality allows for better analysis and study.

\subsection{Task $\mathrm{C}$ - enquiry about plate tectonics}

The problem-solving skills of PSTs were mobilized in task $\mathrm{C}$, as they were faced with the following three challenges:

1. Task $\mathrm{C} 1$ - enquiry about the plate dynamics which should occur to create a non-volcanic mountain range;

2. Task $\mathrm{C} 2$ - enquiry about the plate dynamics which should occur to create an insular arc; 

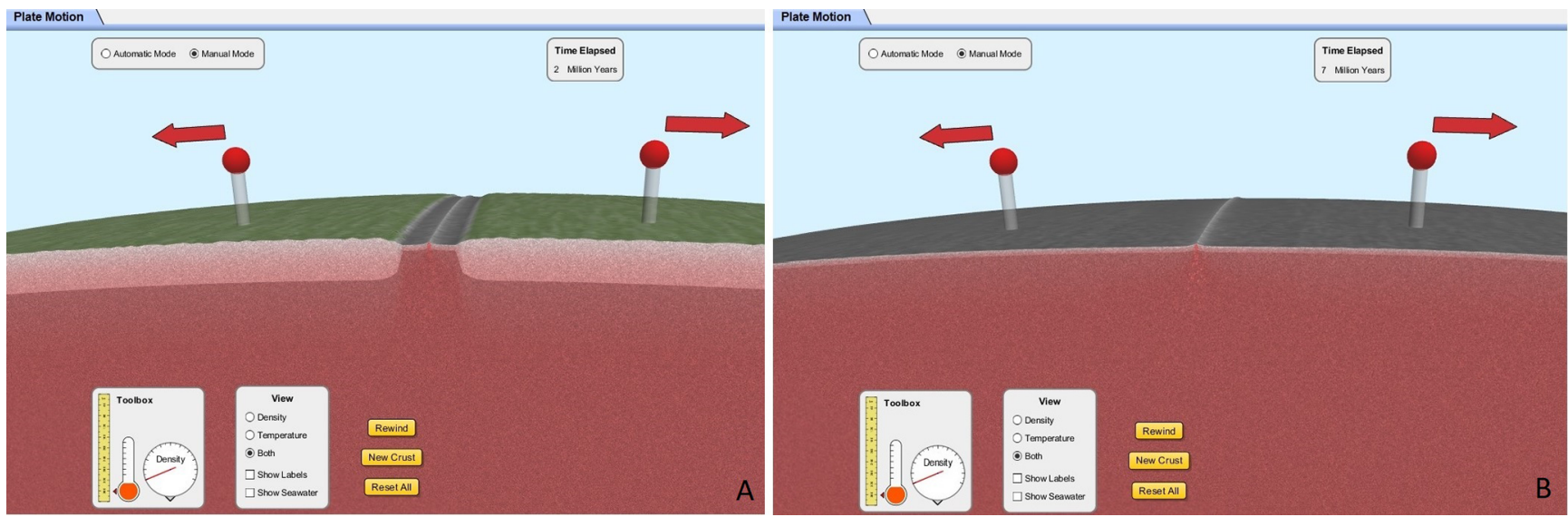

Figure 7. A rift can be formed through the divergence of the continental crust (a) but also through the divergence of old oceanic crust (b). Caption from PhET ${ }^{\mathrm{TM}}$ Plate Tectonics.
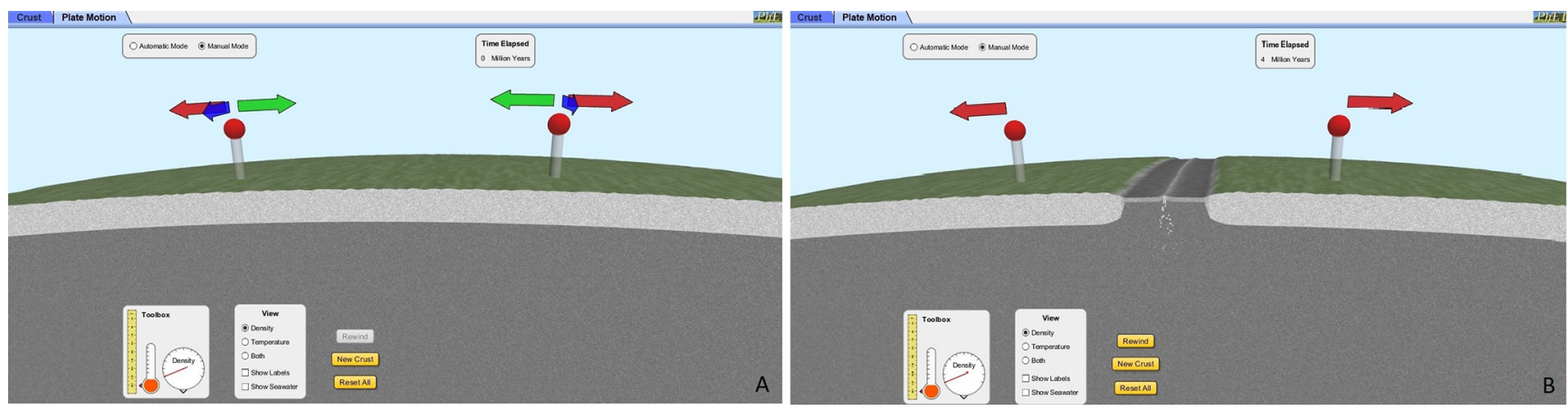

Figure 8. First tectonic situation provided to PSTs (a) and the formation of oceanic crust due to divergent movements (red arrows; b). Caption from PhET ${ }^{\mathrm{TM}}$ Plate Tectonics.

3. Task C3 - enquiry about the plate dynamics which should occur to create a similar process to the one at the San Andreas Fault, California, USA.

Table 4 shows the correct answer for each enquiry and the PST results.

The performance of the PSTs in the three enquiries was also very good, revealing suitable problem-solving skills which reinforces the importance of problem-based learning pedagogy (Tan, 2007). The $\mathrm{C} 1$ enquiry shows PSTs the process of mountain range formation due to the collision of two plates with continental crust, which turns out to be an advantage in avoiding the following misconceptions: "When two continental tectonic plates push together, both plates are pushed upward to form volcanoes" (Mills et al., 2017, p. 303) and "All mountains are volcanoes" (Mills et al., 2017, p. 304).

Concerning the $\mathrm{C} 3$ enquiry, PST performance was better when comparing $\mathrm{C} 1$ with $\mathrm{C} 2$ tasks results. The selected example, which referred to the San Andreas Fault, may have contributed to a better performance by students and leading to their identifying the correct option, since it is part of the reality that students know. This connection to real-world ex- periences is an important point to take into account with regards to simulation exploration (PhET, 2014).

The previous tasks (A and B) contribute to the comprehension of major tectonic plate movements and to the mobilization of conceptual knowledge about plate tectonics necessary for carrying out enquiries C1, C2 and C3. Some PST groups did not answer $\mathrm{C} 1$ and $\mathrm{C} 2$ enquiries correctly due to not exploring all possible combinations of plate movements.

\subsection{Pre-service teachers' evaluation of the educational resource}

Figure 9 shows the level of satisfaction of a PST sample (19 pairs of PSTs; P1 to P19) concerning the contribution of the educational resource to their learning, on a scale of 1 (very unsatisfied) to 10 (very satisfied).

Results show a high level of satisfaction $(\geq 7)$ with the educational resource, which is also confirmed by some of the following comments: "This work proposal is very well structured" (P19), and “... we really enjoyed doing this work proposal very much" (P17). Table 5 shows the categorization 
Table 3. Pre-service teachers' results for B1.1. to B2.2. tasks.

Task

Relative frequency of correct answers $(n=68)$

B1.1. Select the process that occurs as a result of the convergent movement between a plate with continental crust and an old oceanic plate.

Correct answer - "The old oceanic plate suffers subduction under continental crust."

B1.2. Select the process that occurs as a result of the convergent movement between a plate with continental crust and a new oceanic plate.

Correct answer - "The new oceanic plate suffers subduction under continental crust."

B1.3. Compare what happens to the subduction angle when a plate with continental crust collides with an old or new oceanic plate.

Correct answer - "The collision between a plate with continental crust and an old oceanic plate

originates a greater subduction angle than its collision with a new oceanic plate."

B1.4. Compare what happens to the location of volcanoes regarding the continental margin

when a plate with continental crust collides with an old or new oceanic plate.

Correct answer - "The collision of a plate with continental crust and an old oceanic plate

originates volcanoes closer to the continental margin."

B2.1. A rift is only formed due to divergence of continental crust.

$64.7 \%$

Correct answer - "False."

B2.2. The type of plate movement that causes the formation of oceanic crust is...

Correct answer - “... divergent movements (red arrows)."

Table 4. Pre-service teachers' enquiry results for $\mathrm{C} 1$ to $\mathrm{C} 3$.

\begin{tabular}{lr}
\hline Task & $\begin{array}{r}\text { Relative frequency of correct } \\
\text { answers }(n=68)\end{array}$ \\
\hline $\begin{array}{l}\text { C1. Enquiry about the plate dynamics which should occur to create a non-volcanic } \\
\text { mountain range. }\end{array}$ & $91.2 \%$ \\
Correct answer - "Convergent plate boundaries between continental crusts." & $88.2 \%$ \\
\hline C2. Enquiry about the plate dynamics which should occur to create an insular arc. \\
Correct answer - "Convergent plate boundaries between old and new oceanic crust." \\
\hline C3. Enquiry about the plate dynamics which should occur to create a similar process \\
to the one on San Andreas Fault, California. \\
Correct answer - "Transform plate boundaries between continental crusts." \\
\hline
\end{tabular}

of PST responses regarding the evaluation of the educational resource.

Concerning the contributions of the educational resource to their learning, most of the PSTs stated that the PhETTM Plate Tectonics simulator was a good contribution to "Understanding, through observation, the difference between convergent, divergent and transform boundaries and the phenomena that happen when plate movements occur" (P3). This is due to the simulator allowing "... observations of the movement and behaviour of different plates as well as the properties (density, temperature and thickness) of each type of crust..." (P15). Some groups emphasized the "... interactivity of the simulator..." (P11) since it allowed the exploration of "... several hypotheses of transformation according to the data entered" (P17). These ideas and results suggest that PhET ${ }^{\mathrm{TM}}$ Plate Tectonics contributed to the content knowledge of PSTs about plate tectonics, therefore making a contribution to the lack of research about the impact of specific simulators on content knowledge (Phuong et al., 2013). Moreover, these statements are in line with one of the goals of PhET simulations, which is to help students develop and assess their understanding and reasoning about science topics (PhET, 2014).

Some PSTs mentioned that the educational resource contributed to their learning about plate tectonics. However, they did not mention that it was directly due to the use of the simulator. For example, one group considered that "It serves to consolidate knowledge and to (help) better understand the (plate tectonic) processes" (P4). Other groups highlighted the collaboration between PSTs as being very important for 
Table 5. Categorization of the answers from PSTs regarding the contributions of the educational resource to their learning and suggestions for improvement.

\begin{tabular}{|c|c|c|}
\hline Category & Subcategory & $\begin{array}{r}\text { Frequency }(n=19 \\
\text { PST pairs })\end{array}$ \\
\hline \multirow[t]{3}{*}{ Contributions to learning } & $\begin{array}{l}\text { Consolidation of learning regarding plate tectonics resulting from the } \\
\text { use of the PhET }\end{array}$ & 15 \\
\hline & $\begin{array}{l}\text { Consolidation of learning regarding plate tectonics, without } \\
\text { specifically mentioning the use of PhET }\end{array}$ & 3 \\
\hline & PST collaboration resulting from group work & 2 \\
\hline \multirow[t]{3}{*}{ Improvement suggestions } & Absence of improvement aspects & 13 \\
\hline & Instructions for using the simulator & 2 \\
\hline & Other aspects & 4 \\
\hline
\end{tabular}

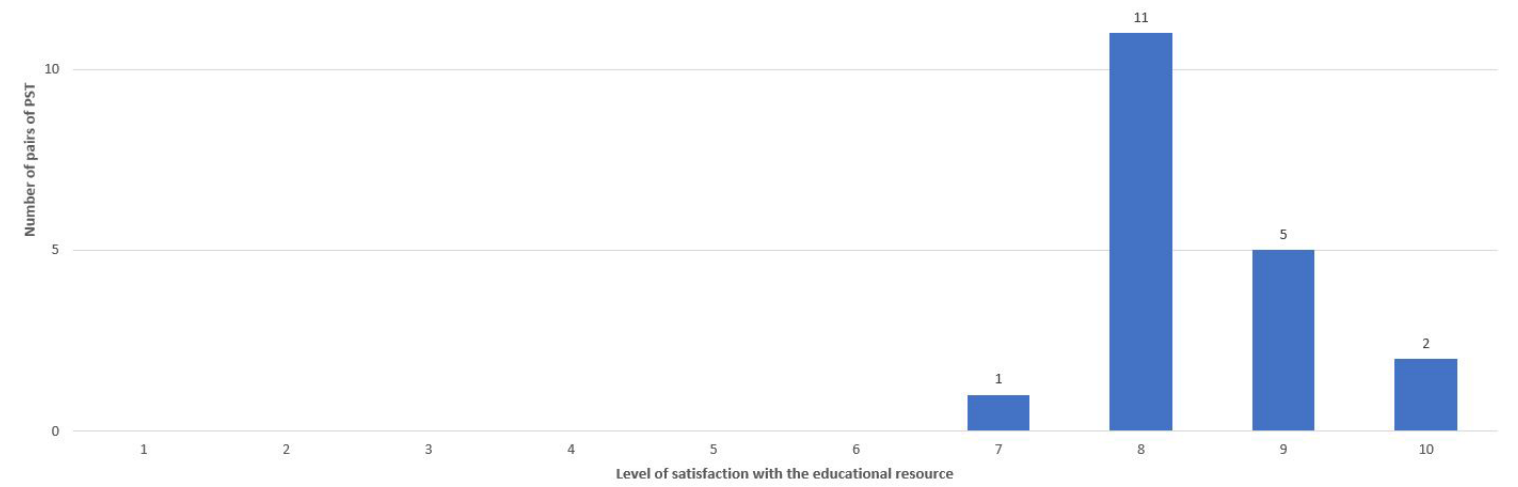

Figure 9. Chart showing evaluations from PSTs concerning the contribution of the educational resource CreativeLab_Sci\&Math | Plate Tectonics to their learning.

exchanging ideas about plate tectonics: "Working in pairs made it easier to understand and allowed the discussion of our ideas" (P6).

Concerning suggestions for improvement, many groups did not present any suggestions. The majority of the PSTs were very pleased with the educational resource and its tasks, as shown in the following statements: "We consider the activity was very well designed, and there are not any aspects to improve" (P3), and "We think the form is very clear, and the simulator helps a lot" (P14). However, two of the groups mentioned difficulties with the use of the simulator, suggesting that "Some questions should include instructions to facilitate the use of the app" (P2). However, this suggestion goes against the didactic guidelines on the use of PhET ${ }^{\mathrm{TM}}$ interactive simulations, which recommend minimal instructions for their use and a free exploration of the content. Other aspects concerned circumstantial situations such as, for example, the work group dynamics: "Since we were working at a distance, there should be a way for each of us to see the form at the same time" (P10). This statement is important to reflect on because PhET's Approach to Guided Enquiry (2014) suggests, in point 6 , that students should "share their ideas with their partner, working together to answer questions." The important moment of sharing ideas among students can be hampered by the difficulty expressed by the previous student (P10).

It was also asked how much time each group spent doing the work. The response range was between 40 and $90 \mathrm{~min}$, with an average of approximately $60 \mathrm{~min}$.

\section{Conclusions}

As in other works about the advantages of using simulators to promote different skills in students and interest in science (Droui, 2014; Hensberry et al., 2013; Lancaster et al., 2013; McKagan et al., 2008; Nafidi et al., 2018; Perkins et al., 2012; Wieman et al., 2010), the present study highlights the 
benefits of the PhET ${ }^{\mathrm{TM}}$ Plate Tectonics interactive simulation in developing the conceptual knowledge of pre-service teachers (PSTs) about plate tectonics, embedded in a structured educational resource with tasks about the characteristics of crust, plate movements and an enquiry about plate tectonics. PSTs successfully achieved the learning outcomes that guided the elaboration of this educational resource. In fact, they were capable of describing the differences between the oceanic crust and continental crust regarding temperature, density, composition and thickness (LO 1), associating the tectonic plate movements with its geological consequences (LO 2), and identifying the tectonic plate movements that cause the formation of some geological structures (LO 3).

Since plate tectonic processes cannot be observed in real time, by using the PhET ${ }^{\mathrm{TM}}$ Plate Tectonics, the PSTs could observe those processes through the simulation of different crust movements and crust types. The tectonic processes observed in the simulator could move PSTs away from misconceptions about plate tectonics, such as those identified by Marques and Thompson (2006) and Mills et al. (2017).

Although the simulator has some limitations because it does not show the mechanism that causes tectonic plate movements nor does it show processes such as back-arc basin formation, we believe it has a high potential to promote conceptual knowledge about plate tectonics in PSTs.

In future approaches, it would be interesting to analyse the potential of using simulators such as the $\mathrm{PhET}^{\mathrm{TM}}$ radioactive dating game to explore other core ideas, such as geological time, which can cause difficulties in comprehension for some students (Dodick and Orion, 2003, 2006).

The CreativeLab_Sci\&Math | Plate Tectonics resource allows the improvement of the understanding of some aspects related to tectonic plate movements and encourages the sharing of ideas between PSTs. The feedback given by PSTs after completing the tasks was quite positive, highlighting their engagement with the simulator and its associated tasks. This fact demonstrates the importance of using simulators to motivate students to learn geology, as defended by some researchers (Nafidi et al., 2018; Quintana et al., 2004 and Pinto et al., 2014). CreativeLab_Sci\&Math | Plate Tectonics has proved to be a useful resource for distance learning, since it can be used autonomously by students in an online context.

Data availability. All data presented in this paper are available from the corresponding author upon request.

Author contributions. BC designed the experiment. BC and SA collected and interpreted the data and contributed to the discussion of the results and the final paper.

Competing interests. The authors declare that they have no conflict of interest.
Acknowledgements. We are grateful to the School of Education of the Polytechnic of Santarém and the School of Education of the Polytechnic of Porto for the logistical support.

Review statement. This paper was edited by Stephanie Zihms and reviewed by Emer Emily Neenan and one anonymous referee.

\section{References}

Almeida, A.: A controversa aceitação da Teoria da Tectónica de Placas à luz das ideias de Kuhn, Revista de Educação, 9, 29-40, 2000.

Bitting, K., McCartney, M., Denning, K., and Roberts, J.: Conceptual learning outcomes of virtual experiential learning: results of google earth exploration in introductory geoscience courses, Res. Sci. Educ., 48, 533-548, https://doi.org/10.1007/s11165016-9577-z, 2018.

Borges, M. C.: Concepções alternativas dos alunos sobre o campo magnético terrestre: implicações na aprendizagem da Teoria da Tectónica de Placas (Dissertação de Mestrado), Departamento de Didática e Tecnologia Educativa, Universidade de Aveiro, Aveiro, 1-200, 2002.

Cavadas, B.: From the contracting earth to continental drift: Wegener's influence on Portuguese and Spanish science textbooks through the twentieth century, Earth Sci. Hist., 38, 74-93, https://doi.org/10.17704/1944-6178-38.1.74, 2019.

Cavadas, B. and Franco, D.: A Teoria da Deriva dos Continentes de Alfred Wegener nos manuais escolares de Ciências Naturais Portugueses, Entretextos, 12, 1-14, 2009.

Cavadas, B., Correia, M., Mestrinho, N., and Santos, R.: CreativeLab_Sci\&Math | Work Dynamics and Pedagogical Integration in Science and Mathematics, Interacções, 15, 6-22, https://doi.org/10.25755/int.18786, 2019.

Cohen, L., Lawrence, M., and Morrison, K.: Research methods in education (6 Edn), Routledge, 1-638, 2007.

COL - Commonwealth of Learning: Keeping the doors of learning open COVID-19, available at: https://www.col.org/resources/ keeping-doors-learning-open-covid-19, last access: 10 May 2020.

Correia, G. M. P.: Paleomagnetismo e tectónica de placas: Desenvolvimento e avaliação de modelos para o ensino (Tese de Doutoramento), Departamento de Ciências da Terra, Faculdade de Ciências e Tecnologia da Universidade de Coimbra, Portugal, $1-405,2014$.

de Jong, T. and Joolingen, W. R. Van: Scientific discovery learning with computer simulations of conceptual domains, Rev. Educ. Res., 68, 179-201, 1998.

Dodick, J. and Orion, N.: Building an understanding of geologic time: A cognitive synthesis of the "macro" and "micro" scales of time, Special Paper of the Geological Society of America, 413, 77-93, 2006.

Dodick, J. and Orion, N.: Measuring student comprehension of geologic time, Sci. Educ., 87, 708-731, 2003.

Dolphin, G. and Benoit, W.: Students' mental model development during historically contextualized inquiry: How the "Tectonic Plate" metaphor impeded the process, Int. J. Sci. Educ., 38, 276297, https://doi.org/10.1080/09500693.2016.1140247, 2016. 
Droui, M. and El Hajjami, A.: Simulations informatiques en enseignement des sciences: apports et limites, EpiNet: Revue électronique de l'EPI, 164, 2014.

Faustino, P., Gomes, C. R., Abrantes, P. and Rola, A.: Historical evolution of plate tectonics and its cartography until the end of the 1960s, and implications in the teaching of earth sciences in Portugal, Memorias R. Soc. Esp. Hist. Nat., 2, 245-285, 2017.

Ferreira, R.: O Google Earth na aprendizagem da "Tectónica de Placas", numa turma de $7 .^{\circ}$ ano de escolaridade (Relatório de Projeto do Mestrado em Ciências da Educação - Especialização em Utilização Pedagógica das TIC), Escola Superior de Educação e Ciências Sociais, Instituto Politécnico de Leiria, Portugal, 1-185, 2016.

Francek, M.: A compilation and review of over 500 geoscience misconceptions. Int. J. Sci. Educ., 35, 31-64, https://doi.org/10.1080/09500693.2012.736644, 2013.

Frankel, J. R., Wallen, N. E., and Hyun, H. H.: How to design and evaluate research in education (8 Edn.), McGraw Hill, 1-710, 2012.

Frankel, H. R.: The Continental Drift Controversy, Volume I: Wegener and the Early Debate, Cambridge University Press, 1-604, 2012a.

Frankel, H. R.: The Continental Drift Controversy, Volume II: Paleomagnetism and confirmation of drift, Cambridge University Press, 1-525, 2012b.

Frankel, H. R.: The Continental Drift Controversy, Volume IV: Evolution into Plate Tectonics, Cambridge University Press, 1-675, 2012c.

Gleen, W. H.: Suggestions for teaching the principles of continental drift in the elementary school, J. Geogr., 76, 57-63, https://doi.org/10.1080/00221347708980883, 1977.

Hensberry, K. K. R., Paul, A. J., Moore, E. B., Podolefsky, N. S., and Perkins, K. K.: PhET Interactive Simulations: New tools to achieve common core mathematics standards, edited by: Polly, D., Common Core Mathematics Standards and Implementing Digital Technologies, IGI Global, 147-167, 2013.

Hoban, G., Loughran, J., and Nielsen, W.: Slowmation: preservice elementary teachers representing science knowledge through creating multimodal digital animations, J. Res. Sci. Teach., 48, 985-1009, https://doi.org/10.1002/tea.20436, 2011.

Lancaster, K. V., Moore, E. B., Parson, R., and Perkins, K.: Insights from using PhET's design principles for interactive chemistry simulations, edited by: Suits, J. and Sanger, M., Pedagogic Roles of Animations and Simulations in Chemistry Courses, ACS Symposium Series, 97-126, 2013.

Marques, L. and Thompson, D.: Misconceptions and conceptual changes concerning continental drift and plate tectonics among Portuguese students aged 16-17, Res. Sci. Tech. Educ., 15, 195222, https://doi.org/10.1080/0263514970150206, 1997.

McKagan, S. B., Perkins, K. K., Dubson, M., Malley, C., Reid, S., LeMaster, R., and Wieman, C. E.: Developing and researching PhET simulations for teaching quantum mechanics, Am. J. Phys., 76, 406, https://doi.org/10.1119/1.2885199, 2008.

Mills, R., Tomas, L., and Lewthwaite, B.: Junior secondary school students' conceptions about plate tectonics, Int. Res. Geogr. Environ. Educ., 26, 297-310, https://doi.org/10.1080/10382046.2016.1262511, 2017.

Mills, R., Tomas, L., and Lewthwaite, B.: The Impact of StudentConstructed Animation on Middle School Students' Learning about Plate Tectonics, J. Sci. Educ. Technol., 28, 165-177, https://doi.org/10.1007/s10956-018-9755-z, 2019.

Nafidi, Y., Alami, A., Zaki, M., El Batri, B., and Afkar, H.: Impacts of the use of a digital simulation in learning Earth sciences (The case of relative dating in High School), J. Turkish Sci. Educ., 15, 89-108, https://doi.org/10.12973/tused.10223a, 2018.

Paige, K., Bentley, B., and Dobson, S.: Slowmation: an innovative twenty-first century learning tool for science and mathematics pre-service teachers, The Australian Journal of Teacher Education, 41, 1-15, https://doi.org/10.14221/ajte.2016v41n2.1, 2016.

Perkins, K., Moore, E., Podolefsky, N., Lancaster, K., and Denison, C.: Towards research-based strategies for using $\mathrm{PhET}$ simulations in middle schools physical science class, PERC Proceedings, AIP Press, 1413, 295-298, https://doi.org/10.1063/1.3680053, 2012.

Perkins, K., Podolefsky, N., Lancaster, K., and Moore, E.: Creating Effective Interactive Tools for Learning: Insights from the PhET Interactive Simulations Project, in: Proceedings of EdMedia 2012-World Conference on Educational Media and Technology, edited by: Amiel, T. and Wilson, B., Denver, Colorado, USA: Association for the Advancement of Computing in Education (AACE), 436-441, available at: https://www.learntechlib. org/primary/p/40781/ (last access: 9 June 2020), 2012.

PhET Interactive Simulations, PhET Professional Development Team: Creating PhET Interactive Simulations Activities, PhET's Approach to Guided Inquiry, available at: https://phet. colorado.edu/en/teaching-resources/activity-guide, (last access: 9 June 2020), 2014.

Phong, T. D., Moreland, J. R., Delgado, C., Wilson, K., Wang, X., Zhou, C., and Ice, P.: Effects of 3D virtual simulators in the introductory wind energy course: A tool for teaching engineering concepts, Innovative Teaching, 2, 1-10, https://doi.org/10.2466/04.07.IT.2.7, 2013.

Pinto, A., Barbot, A., Viegas, C., Silva, A. A., Santos, C. A., and Lopes, J. B.: Teaching Science with Experimental Work and Computer Simulations in a Primary Teacher Education Course: What Challenges to Promote Epistemic Practices?, Proc. Tech., 13, 86-96, https://doi.org/10.1016/j.protcy.2014.02.012, 2014.

Podolefsky, N. S., Perkins, K. K., and Adams, W. K.: Factors Promoting Engaged Exploration with Computer Simulations. Physical Review Special Topics - Phys. Educ. Res., 6, 2017, https://doi.org/10.1103/PhysRevSTPER.6.020117, 2010.

Praia, J.: Formação de professores no ensino da Geologia: contributos para uma didáctica fundamentada na epistemologia das ciências. O caso da Deriva Continental (Tese de Doutoramento), Universidade de Aveiro, Aveiro, Portugal, 1995.

Quintana, C., Reiser, B. J., Davis, E. A., Krajcik, J., Fretz, E., Duncan, R. G., and Soloway, E.: A scaffolding design framework for software to support science inquiry, The Journal of the Learning Sciences, 13, 337-386, https://doi.org/10.1207/s15327809j1s1303_4, 2004.

Santos, M., Sant'Ovaia, H., Moreira, J., and Ribeiro, M. A.: Evolution of the approach of Plate Tectonics in the school textbooks of secondary education - from the sixties to the present, e-Terra, $15,14-44,2010$.

Swain, J.: Designing research education. Concepts and methodologies, SAGE Publications, 1-259, 2017.

Tan, O.: Problem-based learning pedagogies: psychological processes and enhancement of intelligences. Ed- 
ucational Research for Policy and Practice, 6, 101-114, https://doi.org/10.1007/s10671-007-9014-1, 2007.

Trundle, K. and Bell, R.: The use of a computer simulation to promote conceptual change: A quasiexperimental study, Comput. Educ., 54, 1078-1088, https://doi.org/10.1016/j.compedu.2009.10.012, 2010.

Vasconcelos, C., Almeida, A., and Barros, J. A.: Teaching continental drift: Epistemological and historical contributions, J. Sci. Educ., 1, 32-35, 2013.
Wegener, A.: Die Entstehung der Kontinente und Ozeane, The Origin of Continents and Oceans, Friedrich Vieweg \& Sohn Akt. Ges., 1-231, 1922.

Wieman, C., Adams, W., Loeblein, P., and Perkins, K.: Teaching Physics using PhET simulations, The Physics Teacher, 48, 225, https://doi.org/10.1119/1.3361987, 2010.

Wilson, J. T. (Ed.): Continents Adrift and Continents Aground, Readings from Scientific American, W. H. Freeman and Company, 1-230, 1976. 